University of Nebraska - Lincoln

DigitalCommons@University of Nebraska - Lincoln

\title{
Compost and Manure Effects on Fertilized Corn Silage Yield and Nitrogen Uptake under Irrigation
}

\author{
Gary A. Lehrsch \\ United States Department of Agriculture, lehrsch@nwisrl.ars.usda.gov \\ D. C. Kincaid \\ United States Department of Agriculture
}

Follow this and additional works at: https://digitalcommons.unl.edu/usdaarsfacpub

Part of the Agricultural Science Commons

Lehrsch, Gary A. and Kincaid, D. C., "Compost and Manure Effects on Fertilized Corn Silage Yield and Nitrogen Uptake under Irrigation" (2007). Publications from USDA-ARS / UNL Faculty. 566.

https://digitalcommons.unl.edu/usdaarsfacpub/566

This Article is brought to you for free and open access by the U.S. Department of Agriculture: Agricultural Research Service, Lincoln, Nebraska at DigitalCommons@University of Nebraska - Lincoln. It has been accepted for inclusion in Publications from USDA-ARS / UNL Faculty by an authorized administrator of DigitalCommons@University of Nebraska - Lincoln. 


\title{
Compost and Manure Effects on Fertilized Corn Silage Yield and Nitrogen Uptake under Irrigation
}

\author{
Gary A. Lehrsch and D. C. Kincaid \\ United States Department of Agriculture, Agriculture Research Service, \\ Northwest Irrigation and Soils Research Laboratory, Kimberly, \\ Idaho, USA
}

\begin{abstract}
Dairy manure increases the yields of dry bean (Phaseolus vulgaris L.) and spring wheat (Triticum aestivum L.) from eroded, furrow-irrigated soils and may increase corn (Zea mays L.) silage yield from steeper eroded areas under sprinkler irrigation. In a 2-year field study in southern Idaho on Portneuf silt loam (coarse silty, mixed, superactive, mesic Durinodic Xeric Haplocalcid), the effects of a one-time, fall application of 29 or $72 \mathrm{Mg} \mathrm{ha}^{-1}$ of dry manure or 22 or $47 \mathrm{Mg} \mathrm{ha}^{-1}$ of dry compost on subsequent silage yield and nitrogen $(\mathrm{N})$ uptake from previously eroded, sprinkler-irrigated hill slopes were evaluated. In October 1999, stockpiled or composted dairy manure was disked to a depth of $0.15 \mathrm{~m}$ into plots with slopes from 0.8 to $4.4 \%$. After planting field corn in 2000 and 2001, a low-pressure, six-span traveling lateral sprinkler system was utilized to apply water at $28 \mathrm{~mm} \mathrm{~h}^{-1}$ in amounts sufficient to satisfy evapotranspiration to $6.4-\times 36.6-\mathrm{m}$ field plots. Yields in 2000 were $27.5 \mathrm{Mg} \mathrm{ha}^{-1}$, similar among all rates of all amendments and a fertilized control. In 2001, compost applied at oven-dry rates up to $47 \mathrm{Mg} \mathrm{ha}^{-1}$ increased yield compared to controls. Silage yield in 2001 increased initially then decreased with increasing manure applications. Where compost or manure was applied, regardless of rate, 2-year average $\mathrm{N}$ uptake was $15 \%$ greater than controls. Regardless of treatment or year, yields decreased linearly as soil slope increased.
\end{abstract}

Keywords: Corn, erosion, slope, sprinkler irrigation, Zea mays L.

Received 7 June 2006, Accepted 25 September 2006

Address correspondence to Gary A. Lehrsch, United States Department of Agriculture, Agriculture Research Service, Northwest Irrigation and Soils Research Laboratory, 3793 N. 3600 E., Kimberly, ID 83341-5076, USA. E-mail: lehrsch@ nwisrl.ars.usda.gov 


\section{INTRODUCTION}

Approximately 45.4 million $\mathrm{Mg}$ of manure were produced annually in the mid 1990s by dairy and beef cattle, Bos sp. (Walker, southworth, and Rubin 1997, cited by Edwards and Someshwar 2000). In Idaho, the livestock industry has expanded rapidly, with the waste generated becoming a concern. Statewide, Idaho's dairy and beef cattle produce more than 4.5 million $\mathrm{Mg}$ of air-dry manure annually (A. A. Araji, 2005, personal communication). About $70 \%$ of the state's dairy cows and $30 \%$ of the beef cattle are in southcentral Idaho. The growth of the dairy industry in southern Idaho to supply milk for cheese production has significantly increased manure production. The cattle in southern Idaho alone produce more than 2.2 million $\mathrm{Mg}$ of air-dry manure annually. The characteristics and beneficial uses of many different manures were reviewed recently (Edwards and Someshwar 2000; Sumner 2000).

In the intermountain region of the Pacific northwest, much of the manure produced becomes compost. Compost refers to organic constituents, usually wastes, that have been mixed, piled, and moistened and undergo thermophilic decomposition that alters or decomposes the original organic materials (Soil Science Society of America 1997). To ease waste disposal, many local dairy owners compost manure, then recycle the compost as bedding for their cows. In many areas, landscapers, home gardeners, horticulturalists, and others prize compost (Richard 2005). DeLuca and DeLuca (1997) compared the nitrogen $(\mathrm{N})$, phosphorus $(\mathrm{P})$, and potassium $(\mathrm{K})$ concentrations in composted manure with fresh manure and feedlot manure. The compost, and the processes used to produce it, have been described in detail (Richard 2005, Keener et al. 2000).

Organic amendments are often applied to soils to increase crop productivity, crop quality, or both (Bresson et al. 2001; Edmeades 2003; Risse et al. 2001). Compared to noneroded soils, dairy manure applications increased yields of dry bean and spring wheat from eroded soils on a $1.1 \%$ slope in southern Idaho and may increase yields of other crops as well (Robbins, Freeborn, and Mackey 1997; Tarkalson et al. 1998). Fall-applied manure and compost increased corn grain yield and biomass at tasseling for two growing seasons after being applied (Eghball, Ginting, and Gilley 2004). Dairy manure applications increased corn silage yields and soil nitrate $\left(\mathrm{NO}_{3}\right)-\mathrm{N}$ in an Enosburg fine sandy loam (Mollic Haplaquent) in proportion to the application rate (Jokela 1992).

Manure increases soil fertility. In the short-term manure stimulates microbial activity that improves soil structure and in the long-term supplies $\mathrm{NO}_{3}-\mathrm{N}$ and ammonium $\left(\mathrm{NH}_{4}\right)-\mathrm{N}$ to aid crop production (Edwards and Someshwar 2000; Sumner 2000). In a review of literature, Loveland and Webb (2003) noted that annual manure applications may increase yields, even where fertilizer is applied, possibly because of increases in soil organic carbon or available water. Increased available water may have played a role, given that Arriaga and Lowery (2003) found that annual 
manure applications increased water retention proportionally more on eroded than noneroded sites. They attributed the increased yields where manure was applied to greater water retention in amended soils. Manure applications may also increase the productivity of soils degraded by erosion from irrigation or rainfall (Arriaga and Lowery 2003; Carter 1990). Compost and fresh manure provide similar benefits for both crop production and soil management, along with others as well. Compared to manure, compost contains few viable weed seeds, less water, and occupies 30 to $60 \%$ less volume, thus decreasing transportation costs (Richard 2005). Organic amendments also stimulate microbes to produce polysaccharides and other exudates that increase aggregate stability (Lehrsch 1995; Lehrsch et al. 1991). Stable aggregates at and near the soil surface resist breakdown from raindrop or sprinkler droplet kinetic energy and sustain infiltration rates (Lehrsch and Kincaid 2001; 2006).

Caution must be exercised, however, when applying large quantities of organic amendments to soil (Amlinger et al. 2003; Edwards and Someshwar 2000). Depending upon the proportion of monovalent cations, principally $\mathrm{K}^{+}$and sodium $\left(\mathrm{Na}^{+}\right)$, to divalent cations in the waste, additions on the order of $100 \mathrm{Mg} \mathrm{ha}^{-1}$ or more can disperse aggregates and destroy surface soil structure, reducing both infiltration and hydraulic conductivity as a consequence (Haynes and Naidu 1998; Lehrsch and Kincaid 2001; Tiarks, Mazurak, and Chesnin 1974). If the added amendments contain large proportions of straw, high in $\mathrm{C}$ but low in $\mathrm{N}$, soil $\mathrm{N}$ may be immobilized (Brown 1988).

Manure from cattle feedlots can contain high concentrations of soluble salts, principally sodium chloride. If applied at high rates in arid or semiarid areas, manure can increase salinity sufficiently to hinder the germination of salt-sensitive crops (Eghball, Ginting, and Gilley 2004; Haynes and Naidu 1998; Sumner 2000). Ammonium ions, added with manure or formed as organic $\mathrm{N}$ compounds are mineralized, will react with water in calcareous soils to form ammonia that, if present in sufficiently high concentrations, will be toxic to germinating seeds and seedlings (Robbins and Gavlak 1989; Tisdale and Nelson 1975). Hao and Chang (2003) reported that annual applications of cattle feedlot manure to an irrigated clay loam in semi-arid southern Alberta increased the electrical conductivity of a saturated paste extract, $\mathrm{EC}_{\mathrm{e}}$. Soluble $\mathrm{Na}^{+}, \mathrm{K}^{+}$, magnesium $\left(\mathrm{Mg}^{2+}\right)$, chloride $\left(\mathrm{Cl}^{-}\right)$, bicarbonate $\left(\mathrm{HCO}_{3}^{-}\right)$, and sodium adsorption ratio (SAR) all increased with fall manure applications ranging from 60 to $180 \mathrm{Mg} \mathrm{ha}^{-1}$. Potassium became the dominant cation on the exchange complex where manure was applied. Hao and Chang (2003) concluded that high manure application rates were not sustainable, leading to salinization without irrigation and possible groundwater contamination with irrigation.

Sustainable crop production in the western United States is made difficult not only by possible soluble salt accumulation but also by problems inherent with irrigating sloping fields. Many previously furrow irrigated fields with medium-textured soils have eroded areas with reduced infiltration capacity 
and/or low fertility (Carter 1990; Rasmussen and Cary 1979). Furrow irrigation-induced erosion from slopes $<2 \%$ is generally not serious if the flow rate is carefully controlled (Carter 1990). Under the outer spans of center pivot irrigation systems, however, one is less able to control runoff and erosion, particularly from slopes $\geq 2.5 \%$ (Lehrsch, Bjorneberg, and Sojka 2005; Lehrsch and Kincaid 2005). Though center pivot systems are becoming common in the Pacific Northwest because of their low labor requirement and capability to irrigate large fields with rolling topography, they tend to produce runoff due to high application rates inherent with traveling lateral systems (Kincaid 2005).

Runoff also erodes soil (Lehrsch, Bjorneberg, and Sojka 2005). After topsoil is eroded by runoff from irrigation, moldboard plowing or disking commonly mixes less fertile, poorly structured subsoil into the Ap horizon, with the proportion of subsoil increasing as erosion increases (Carter 1990). Compared to Portneuf silt loam topsoil, subsoil has half as much organic C, a higher $\mathrm{pH}$, and three times as much calcium carbonate $\left(\mathrm{CaCO}_{3}\right)($ Robbins, Freeborn, and Mackey 1997). Subsoil also hinders root growth and requires much more $\mathrm{P}$ fertilizer to reach adequate levels for crop production (Rasmussen and Cary 1979). Corn growth and development are hindered where topsoil has been eroded by irrigation (Carter 1990).

This research was part of a larger investigation in which amendment effects on runoff, sediment loss, soil structure, nutrient losses in runoff, and to a lesser degree silage yield from sloping field areas were studied. In the research reported here, the effects of stockpiled or composted dairy manure, each at two rates, on corn silage yield and $\mathrm{N}$ uptake from sprinkler irrigated plots with slopes from 0.8 to $4.4 \%$ were determined.

\section{MATERIALS AND METHODS}

The experiment was conducted for 2 years on structurally unstable Portneuf silt loam about $2.1 \mathrm{~km}$ southwest of Kimberly, ID (42 $31^{\prime} \mathrm{N}, 114^{\circ} 22^{\prime} \mathrm{W}$, and elevation of $1190 \mathrm{~m}$ ). The Portneuf's Ap horizon contained about

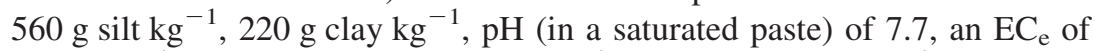
$1.1 \mathrm{dS} \mathrm{m}^{-1}, 75 \mathrm{~g} \mathrm{CaCO}_{3}$ equivalent $\mathrm{kg}^{-1}$, and about $9.3 \mathrm{~g} \mathrm{~kg}^{-1}$ of organic carbon (C). Though the Portneuf's underlying Bk horizon was similar in many respects, it commonly contained nearly three times as much $\mathrm{CaCO}_{3}$ and half as much organic C. Other properties of a nearby Portneuf pedon were given by Lehrsch, Sojka, and Westermann (2000). After harvesting wheat in August 1999, the stubble was chopped and disked on 14-15 September 1999 before the amendments were applied.

Treatments consisted of two amendments, compost and manure, each applied air dry at a medium and high rate, along with an unamended but fertilized control that was duplicated in each block. Compost was applied once at an equivalent oven-dry rate of 22 or $47 \mathrm{Mg} \mathrm{ha}^{-1}$, whereas the manure was 
applied once at an oven-dry rate of 29 or $72 \mathrm{Mg} \mathrm{ha}^{-1}$. The medium and high rates for each amendment were chosen based upon supplying mineral $\mathrm{N}$ as fertilizer in moderate and in excessive amounts, respectively. Because the primary purpose of the larger investigation was to evaluate compost and manure effects on runoff, sediment loss, soil structure, and runoff nutrient losses, an unfertilized check was not included.

Each of the four amendment treatments and the duplicated control were randomly assigned to one of the six, 6.4-m-wide by 36.6-m-long plots under each of the six spans of the irrigation system (described later). After harvesting wheat (Triticum aestivum L.) in August 1999, the stubble was chopped and disked on 14-15 September 1999. On 14 October 1999, the amendments were applied in a broadcast manner with an 18-Mg truck equipped as a manure spreader. Amendment application rates were measured using a 2.24-m-wide by $1.70-\mathrm{m}$-long tarp placed across each plot. The spreader passed repeatedly across a plot until that plot had received its nominal allotment of either compost or manure. After applying $23 \mathrm{~mm}$ of water with a traveling lateral sprinkler system (described later) the next day, the amendments were incorporated on 18-19 October 1999 by disking the entire area to a depth of $0.15 \mathrm{~m}$ three times in two directions.

When the amendments were applied, three samples of compost and five samples of manure were collected for chemical characterization. For collection, the material on a tarp was mixed, then sampled. At the laboratory, a subsample was removed to determine dry-matter content, and then the remainder was immediately air dried at about $30^{\circ} \mathrm{C}$ in a forced-air drying cabinet. The air-dry material was stored at room temperature until, just before analysis, it was ground in a Wiley ${ }^{1}$ mill to pass an $865-\mu \mathrm{m}$ stainless steel screen. On each ground sample, $\mathrm{pH}$ (Wolf 2003b), electrical conductivity (EC) (Wolf 2003a), and total C and $\mathrm{N}$ by the combustion of a 25-mg sample in a Thermo-Finnigan FlashEA1112 CNS analyzer (CE Elantech Inc., Lakewood, N.J.) were determined. An automated flow injection analyzer was utilized to colorimetrically determine each sample's $\mathrm{NO}_{3}-\mathrm{N}$ concentration after cadmium reduction of a potassium chloride $(\mathrm{KCl})$ extract (method 12107-04-1-B, Lachat Instruments, Loveland, Col) and $\mathrm{NH}_{4}-\mathrm{N}$ concentration using a salicylate-hypochlorite method (method 12-107-06-2-A, Lachat Instruments, Loveland, Col).

On 21 April 2000 before planting, soil samples were collected to a depth of $0.3 \mathrm{~m}$ from the controls and analyzed for phosphorus $(\mathrm{P}), \mathrm{K}$, and zinc $(\mathrm{Zn})$. Upon analysis, the macronutrient concentrations were $7 \mathrm{mg} \mathrm{Pg}^{-1}$ and $110 \mathrm{mg} \mathrm{K} \mathrm{kg}^{-1}$. The soil's $\mathrm{Zn}$ concentration was adequate to produce corn, Zea mays L. (Brown and Westermann 1988). After tilling the site with an offset disk to a depth of $0.15 \mathrm{~m}$ on 28 April and again on 2 May, soil samples were collected to $0.3 \mathrm{~m}$ from every plot of the study. Thereafter,

\footnotetext{
${ }^{1}$ Manufacturer or trade names are included for the readers' benefit. The USDA-ARS neither endorses nor recommends such products.
} 
fertilizer was broadcast applied $\left(202 \mathrm{~kg} \mathrm{Nha}^{-1}, 98 \mathrm{~kg} \mathrm{Pha}^{-1}\right.$, and $139 \mathrm{~kg} \mathrm{~K} \mathrm{ha}^{-1}$ ) equally to all plots per University of Idaho soil-test recommendations for irrigated field corn (Brown and Westermann 1988). All fertilizer was incorporated by roller-harrowing to $65 \mathrm{~mm}$. Pioneer $3751 \mathrm{corn}$, a cultivar adapted best for silage production, was planted at a depth of $51 \mathrm{~mm}$ to a nominal plant population of 68,900 plants $\mathrm{ha}^{-1}$ on 12 May into $0.76-\mathrm{m}$ rows oriented perpendicular to the irrigation system lateral (described later). Subsequent cultivation produced small furrows between adjacent corn rows that directed runoff downslope. Each plot's long axis was perpendicular to the irrigation lateral. Plot slopes faced south and ranged from 0.8 to $4.4 \%$, increasing gradually, in general, from span 1 to 6 . Plants from $3.05 \mathrm{~m}$ of an interior row about $12 \mathrm{~m}$ upslope from the downslope plot border and another $3.05 \mathrm{~m}$ of row about $24 \mathrm{~m}$ upslope from the same border in late September, were hand-harvested for silage yield and $\mathrm{N}$ uptake. Subsamples of the harvested silage were weighed, dried at $60^{\circ} \mathrm{C}$, and then weighed again. Dry silage was ground in a Wiley mill to pass a $380-\mu \mathrm{m}$ stainless steel screen. Thereafter, its total $\mathrm{N}$ concentration was determined from a 25mg sample in the CNS analyzer described previously. Yields and $\mathrm{N}$ uptake from the two rows were averaged prior to statistical analysis. In 2001, field operations and timing were similar. All plots were disked to $0.15 \mathrm{~m}$ twice in the spring. On 25 April, $101 \mathrm{~kg} \mathrm{~N} \mathrm{ha}^{-1}$ (as urea, $0.45 \mathrm{~kg} \mathrm{~N} \mathrm{~kg}^{-1}$ ) and $98 \mathrm{~kg} \mathrm{Pha}{ }^{-1}$ were broadcast onto the entire study site, then incorporated with a roller harrow prior to planting corn on 9 May. In both 2000 and 2001, standard cultural practices were employed to control insects and weeds (Brown and Westermann 1988). Despite efforts, yields in 2001 were reduced somewhat by green foxtail, Setaria viridis (L.) P. Beauv.

All plots were irrigated using a 247-m, six-span traveling lateral sprinkler system equipped with spray heads having spinning, six-groove deflector plates and $138-\mathrm{kPa}$ pressure regulators. The sprinklers were mounted $2.4 \mathrm{~m}$ above the soil surface and $3.05 \mathrm{~m}$ apart. Spray pattern width was about $16 \mathrm{~m}$, resulting in an average application rate of about $28 \mathrm{~mm} \mathrm{~h}^{-1}$ (Kincaid 2005) and a peak rate of $40 \mathrm{~mm} \mathrm{~h}^{-1}$ where sprinkler patterns overlapped along the lateral. Automatic valves controlled the flow to each span. The lateral's discharge rate was $7.45 \mathrm{~L}(\operatorname{min~m})^{-1}$, representative of middle spans of a typical center pivot lateral in southern Idaho. On average, corn was irrigated two to three times per week in amounts sufficient to replace calculated evapotranspiration. Spans 1 to 5 received the same gross water application. Slightly less water was applied to steeper plots, particularly those in span 6, on only six days in 2000 and two in 2001, when runoff was measured. Each season, those plots received about $8 \%$ less water than the remaining plots. To spans 1 through 5 , a total of $480 \mathrm{~mm}$ of water in 2000 and $530 \mathrm{~mm}$ in 2001 was applied. The irrigation water, withdrawn from the Snake River, commonly has a $\mathrm{pH}$ of 8.2, an EC of $0.5 \mathrm{dS} \mathrm{m}^{-1}$, and SAR of 0.65 . For most irrigations each year, the lateral traveled uphill. 
The experimental design was a randomized complete block with one block under each of the six spans of the irrigation system. Before performing an analysis of variance (ANOVA), the relationship between each response variable's mean and standard deviation (SD) was examined to ensure that no transformation was needed to stabilize the variable's error variance before analysis. An ANOVA was performed using mixed-model procedures and a significance probability of 5\%, for the most part (SAS Institute Inc. 1999). Random factors were span, span $\times$ year, span $\times$ treatment, and span $\times$ year $\times$ treatment. When each amendment was analyzed separately, random factors were span, span $\times$ year, span $\times$ rate, and span $\times$ year $\times$ rate. In the ANOVA for each amendment, contrasts were used to test for linear and quadratic (curvilinear) trends in yield response to increasing application rate each year. For the most complex trend found significant, a regression equation was fitted to the data. When the equation was curvilinear, the quadratic equation's first derivative was set equal to zero and solved for the amendment's application rate that maximized silage yield. Yield variation accounted for by the blocking factor span was included in each regression model's sum of squares by including span as a class variable in the fitted model, thus giving a more accurate $R^{2}$ estimate.

\section{RESULTS AND DISCUSSION}

\section{Amendment Properties}

The compost and manure that was applied were similar, in general, to that common in the area (Table 1). There were, however, three exceptions. The total $\mathrm{N}$ concentration of the compost was somewhat lower than the common $16.3 \mathrm{~g} \mathrm{~N} \mathrm{~kg}^{-1}$ in compost. The compost EC was 1.9 times the local

Table 1. Properties of the compost and manure (all measurements on a dry-weight basis)

\begin{tabular}{lccccc}
\hline & \multicolumn{2}{c}{ Compost $(n=3)$} & & \multicolumn{2}{c}{ Manure $(n=5)$} \\
\cline { 2 - 3 } Amendment property & Mean & $\mathrm{SD}^{a}$ & & Mean & $\mathrm{SD}$ \\
\hline $\mathrm{pH}$ & 9.26 & 0.03 & & 8.6 & 0.5 \\
Total C $\left(\mathrm{g} \mathrm{kg}^{-1}\right)$ & 111 & 11 & & 289 & 22 \\
Total N $\left(\mathrm{g} \mathrm{kg}^{-1}\right)$ & 11.7 & 1.0 & & 21.2 & 1.5 \\
$\mathrm{NO}_{3}-\mathrm{N}\left(\mathrm{mg} \mathrm{kg}^{-1}\right)$ & 940 & 140 & & 120 & 60 \\
$\mathrm{NH}_{4}-\mathrm{N}\left(\mathrm{mg} \mathrm{kg}^{-1}\right)$ & 85 & 5 & & 326 & 20 \\
$\mathrm{C}: \mathrm{N} \mathrm{Ratio}$ & 9.5 & 0.2 & & 13.6 & 0.2 \\
Electrical conduc- & 10.9 & 1.0 & & 11 & 2 \\
tivity $\left(\mathrm{dS} \mathrm{m}{ }^{-1}\right)$ & & & & \\
\hline
\end{tabular}

${ }^{a} \mathrm{SD}=$ standard deviation. 
Table 2. Amendments applied with the plant-available $\mathrm{N}$ added in each for the first year

\begin{tabular}{|c|c|c|c|c|c|c|}
\hline \multirow[b]{2}{*}{ Amendment $^{a}$} & \multirow[b]{2}{*}{ Treatment } & \multirow{2}{*}{$\begin{array}{c}\text { Application rate } \\
\text { (dry material) } \\
\mathrm{Mg} \mathrm{ha}^{-1}\end{array}$} & \multicolumn{4}{|c|}{ Nitrogen $\operatorname{added}^{b}\left(\mathrm{~kg} \mathrm{ha}^{-1}\right)$} \\
\hline & & & $\mathrm{NO}_{3}-\mathrm{N}$ & $\mathrm{NH}_{4}-\mathrm{N}$ & Min- $\mathrm{N}^{c}$ & Total \\
\hline None & None & 0 & 0.0 & 0.0 & 0 & 0 \\
\hline Compost & Medium & 22 & 21.1 & $1.9(0.1)$ & 50 & 73 \\
\hline Compost & High & 47 & $44.3(6.5)$ & $4.0(0.3)$ & 100 & 148 \\
\hline Manure & Medium & 29 & $3.6(1.8)$ & $9.5(0.6)$ & 270 & 283 \\
\hline Manure & High & 72 & $8.9(4.5)$ & $23.4(1.5)$ & 670 & 702 \\
\hline
\end{tabular}

\footnotetext{
${ }^{a}$ As applied, the compost was $0.71 \mathrm{~kg} \mathrm{dry}$ matter $\mathrm{kg}^{-1}$ and the manure was $0.53 \mathrm{~kg}$ dry matter $\mathrm{kg}^{-1}$.

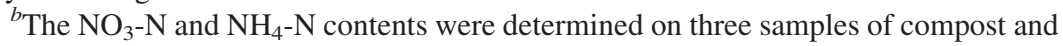
five samples of manure collected when applied. Figures in parentheses are standard deviations.

${ }^{c}$ An estimate, based upon each amendment's total $\mathrm{N}$ concentration, of the $\mathrm{N}$ mineralized in the 12 months after the amendment was applied. Total $\mathrm{N}$ averaged $11.7 \mathrm{~g} \mathrm{~kg}^{-1}$ in compost and $21.2 \mathrm{~g} \mathrm{~kg}^{-1}$ in manure (Table 1). We assumed that the $\mathrm{N}$ mineralized in the first year was $200 \mathrm{~g} \mathrm{~kg}^{-1}$ from compost and $450 \mathrm{~g} \mathrm{~kg}^{-1}$ from manure (DeLuca and DeLuca 1997; Moffitt 1992; Richard 2005).
}

compost average, $5.6 \mathrm{dS} \mathrm{m}^{-1}$, whereas the manure EC was 1.5 times the local manure average, $7.2 \mathrm{dS} \mathrm{m}^{-1}$ (Lehrsch, unpublished). Each amendment's EC, however, was well within two standard deviations of its local average. As expected, the compost contained more $\mathrm{NO}_{3}-\mathrm{N}$ and less $\mathrm{NH}_{4}-\mathrm{N}$ than the manure. When applied, the dry-matter content was $0.71 \mathrm{~kg} \mathrm{~kg}^{-1}$ for compost and $0.53 \mathrm{~kg} \mathrm{~kg}^{-1}$ for manure. The manure's dry-matter content confirms that the material was stockpiled, rather than freshly scraped from a feedlot's surface, prior to application.

The $\mathrm{N}$ added in the medium and high rates of each amendment are shown in Table 2. The standard deviations reveal the variability inherent in estimating the $\mathrm{N}$ applied in these agricultural by-products (Risse et al. 2001). The greatest portion by far of the total plant-available $\mathrm{N}$ added in each amendment was the estimated, first-year mineralized $\mathrm{N}$, being $68 \%$ for compost and $95 \%$ for manure. In total, the medium manure treatment added 3.9 times more $\mathrm{N}$ than the medium compost treatment, whereas the high manure treatment added 4.7 times more $\mathrm{N}$ than the high compost treatment.

\section{Silage Yield}

The ANOVA's year $\times$ treatment interaction was not significant at $P=0.05$ but was at $P<0.078$. Moreover, a single degree-of-freedom comparison 


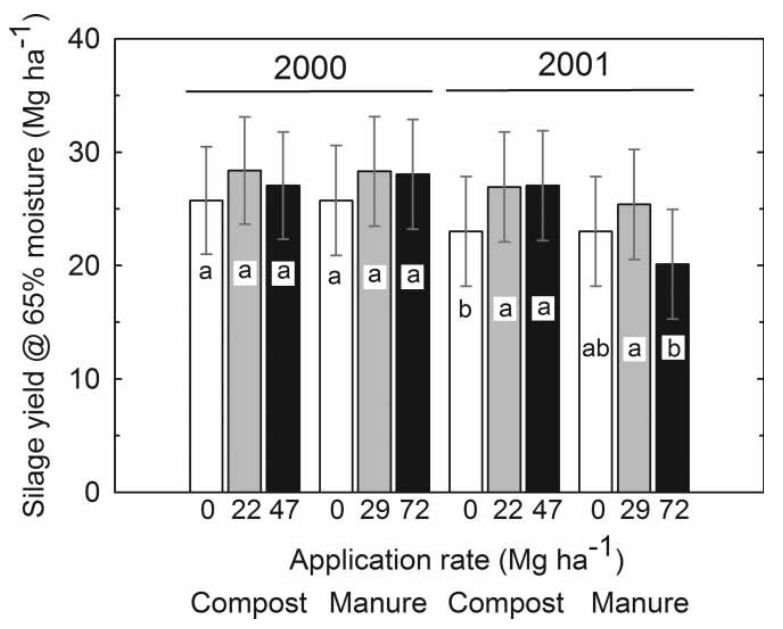

Figure 1. Compost and manure rate effects on silage yield in 2000 and 2001. Within amendments each year, means with a common letter are not significantly different according to $t$ tests of pairwise differences at $P=0.05$. Data from controls are shown twice each year to facilitate comparison with each amendment. Each mean ( $n=12$ for controls, else $n=6$ ) is shown with its $95 \%$ confidence interval.

found that, averaged across medium and high rates, compost effects differed $(P<0.006)$ from manure effects in 2001. In addition, the $146 \mathrm{~mm}$ of precipitation in the first winter (November 1999 through April 2000) after amendment application were $30 \%$ greater than the precipitation in the second winter (November 2000 through April 2001). These factors led to the need to investigate amendment effects each year, particularly in view of the pre-planned analyses of trends in silage yield response to increasing amendment rates.

Though each rate of manure added much more $\mathrm{N}$ than each rate of compost, 2000 yields differed little (Figure 1). Moreover, there was little difference in 2000 silage yields between rates for each amendment. Yields in 2000 from all treatments, including the fertilized control, averaged $27.5 \mathrm{Mg} \mathrm{ha}^{-1}$. Compared to the fertilized control, compost on average increased yields by $8 \%$ and manure by $9 \%$, though neither increase was significant at $P=0.05$. These increases were apparently in response to the amendments applied the preceding fall (Table 2).

In 2000, compost treatments tended to yield more silage than the control (Figure 1). That tendency continued and strengthened the succeeding year. Yield from each of the compost treatments in the second year after application exceeded that of the fertilized control by about $4 \mathrm{Mg} \mathrm{ha}^{-1}$, significant at $P=0.051$ for the medium treatment and at $P=0.045$ for the high. In contrast, neither manure rate affected silage yield in 2001. In fact, the high 
manure rate, $72 \mathrm{Mg} \mathrm{ha}^{-1}$, tended to decrease silage yield, compared to the control.

Though the 2001 yields from the medium and high compost treatments did not differ from one another, the corresponding yields from the manure treatments did (Figure 1). For the manure, the $72 \mathrm{Mg} \mathrm{ha}^{-1}$ treatment yielded less $(P<0.013)$ than the $29 \mathrm{Mg} \mathrm{ha}^{-1}$ treatment. Perhaps the additional straw added in the high manure treatment led to continued microbial immobilization of available soil $\mathrm{N}$ that reduced silage yield (Brown 1988). Another possible explanation is that reduced arbuscular mycorrhizal fungi colonization of the corn as a consequence of the additional nutrients added with the high manure rate may have reduced yields (Tarkalson et al. 1998). Larney et al. (2000), in contrast, found that $75 \mathrm{Mg}$ manure $\mathrm{ha}^{-1}$ restored productivity on simulated eroded areas, though for spring wheat rather than corn silage and grown under predominantly dryland rather than irrigated conditions. In this study, the silage yield from the high manure treatment in 2001 was less than $(P<0.001)$ that from the high compost treatment in 2001. This was surprising, given that all plots of the study received a uniform application of conventional $\mathrm{N}$ and $\mathrm{P}$ fertilizer on 25 April 2001 prior to planting.

Silage yield in 2001 responded in a quadratic manner $(P<0.005)$ to increasing manure rates (Figure 2). Indeed, data shown in Figure 1 reveal that the yield response to manure in 2000, the first growing season after application, was also curvilinear, though not significant at $P<0.05$. One might speculate that soluble salts were responsible for the 2001 yield decrease where

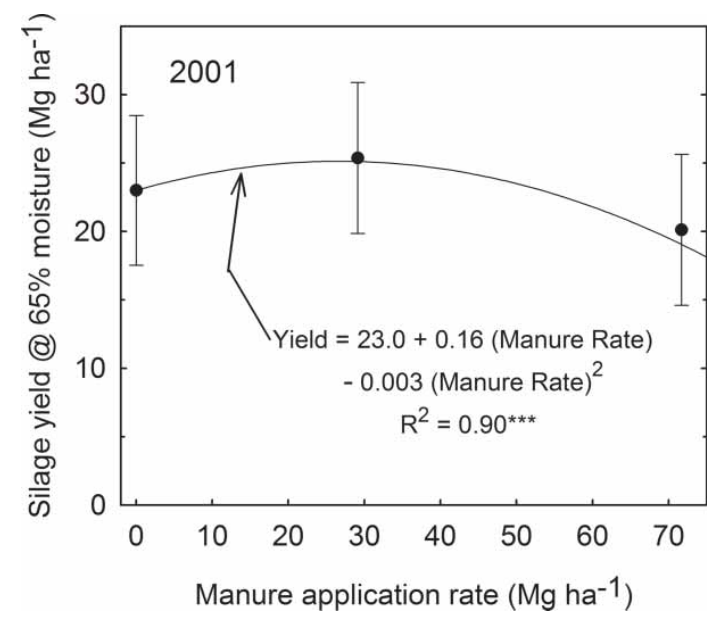

Figure 2. Manure effects on silage yield in 2001. Each mean $(n=12$ for controls, else $n=6$ ) is shown with its $95 \%$ confidence interval. The reported $R^{2}$ is that found after including yield variation accounted for by the blocking factor span in the fitted model's sum of squares. 
$72 \mathrm{Mg}$ manure ha ${ }^{-1}$ were applied. Based upon the amendments' EC values, however, the loads of soluble salts (as total dissolved solids) added directly in the compost and manure were not great. The medium rate added $0.32 \mathrm{Mg}$ soluble salts $\mathrm{ha}^{-1}$ in compost and $0.83 \mathrm{Mg} \mathrm{ha}^{-1}$ in manure. The high rate added $0.68 \mathrm{Mg} \mathrm{ha}^{-1}$ in compost and $2.06 \mathrm{Mg} \mathrm{ha}^{-1}$ in manure. Portneuf silt loam under irrigation typically contains about $0.54 \mathrm{Mg}$ soluble salts ha ${ }^{-1}$ in the upper $0.15 \mathrm{~m}$ where no amendments have been applied. Salt added with the high manure treatment, in the absence of leaching, could have hindered the yield of some salt-sensitive crops, such as dry bean (Phaseolus vulgaris L.), if planted shortly after amendment incorporation. In this experiment, however, 2001 yield decreases from soluble salt loads were unlikely because corn was planted, a more salt-tolerant crop than dry bean. Moreover, soluble salts were surely leached from the seeding depth by 1) the 23-mm irrigation one day after applying the amendments in fall 1999, 2) precipitation in the winters of 1999-2000 and 2000-2001, and 3) percolation during the 2000 growing season (Wright, Westermann, and Lehrsch 1998).

Decreased infiltration is not responsible for yield decreases shown in Figure 2 because a preliminary analysis of runoff (not reported) suggested that infiltration increased slightly with increasing manure rates as Rasmussen and Cary (1979) speculated. Increased infiltration, with attendant leaching of $\mathrm{NO}_{3}-\mathrm{N}$, however, could explain the decrease in yield at high manure application rates if the corn was $\mathrm{N}$ deficient but no symptoms of $\mathrm{N}$ deficiency were observed. Robbins, Freeborn, and Mackey (1997), 3 years after applying fresh manure to the same soil near the experimental site, found that manure increased dry bean yields compared to those from nonmanured plots. However, they applied manure at a greater (air-dry) rate, $137 \mathrm{Mg} \mathrm{ha}^{-1}$, in a split application with $44 \mathrm{Mg} \mathrm{ha}^{-1}$ applied in the spring and the balance in the fall.

Compared to medium or more moderate rates, high rates of either compost or manure did not increase yields, and in some cases, decreased them (Figures 1 and 2). Where excessive rates of compost or manure are applied to produce crops, dispose of agricultural by-products, or both, caution should be exercised not only because of yield reductions but also because of nutrient-use inefficiencies and possible contamination of both surface and groundwater.

\section{Nitrogen Uptake}

Both compost and manure significantly increased 2-year average $\mathrm{N}$ uptake by corn silage (Figure 3). Wherever compost or manure was applied, regardless of rate, $\mathrm{N}$ uptake averaged $230 \mathrm{~kg} \mathrm{ha}^{-1}, 15 \%$ more than controls. Uptake did not differ between amendments or rates. The fact that similar amounts of $\mathrm{N}$ were taken up is somewhat surprising given that the amendments added from 


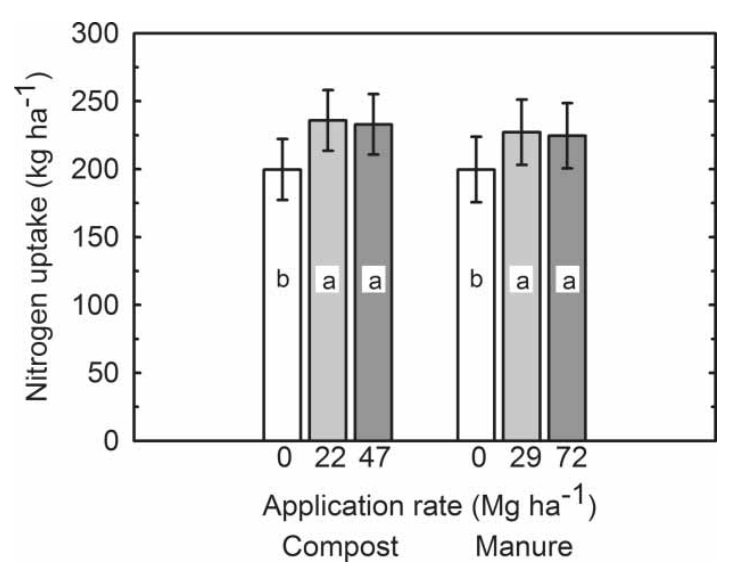

Figure 3. Nitrogen uptake affected by amendment and rate. Data are averaged across years. Means with a common letter are not significantly different according to $t$ tests of pairwise differences at $P=0.05$, with one exception. $\mathrm{N}$ uptake from $72 \mathrm{Mg}$ manure ha $^{-1}$ differed at $P=0.057$ from the control. Data from controls are shown twice to facilitate comparison with each amendment. Each mean $(n=24$ for controls, else $n=12$ ) is shown with its $95 \%$ confidence interval.

73 to $702 \mathrm{~kg} \mathrm{ha}^{-1}$ of plant-available $\mathrm{N}$ in the first year, a ten-fold range (Table 2). Uptake efficiency obviously decreased as application rate increased.

As expected, more $\mathrm{N}$ was taken up (significant at $P=0.029$ ) in the first year after amendment application, compared to the second year (not shown). In 2000, all treatments including controls took up an average of $245 \mathrm{~kg} \mathrm{~N}^{-1}$ but only $203 \mathrm{~kg} \mathrm{~N} \mathrm{ha}^{-1} 1$ year later. Decreased uptake in the second year was likely a consequence of 1) less $\mathrm{N}$ available because some had been removed in the silage the year before, 2) less $\mathrm{N}$ mineralized from the amendments' organic matter (Moffitt 1992), and 3) possible N leaching losses during the first year's growing season and subsequent nongrowing season (Liang, Remillard, and Mackenzie 1991; Wright, Westermann, and Lehrsch 1998).

A single degree-of-freedom comparison of 2001 data revealed, however, that corn growing in compost-amended plots took up $225 \mathrm{~kg} \mathrm{~N} \mathrm{ha}^{-1}$, nearly $17 \%$ more (significant at $P=0.022$ ) than in manure-amended plots. This finding is in part a consequence of the relatively low silage yield from the manure-amended plots in 2001 (Figure 1). Greater uptake in 2001 from compost-treated than manure-treated plots could also be attributed to the slower but steadier mineralization of $\mathrm{N}$ from the more recalcitrant organic matter added in the compost. Also, soil and fertilizer $\mathrm{N}$ may have been immobilized in microbial tissues as a consequence of the straw added in the manure, particularly for the low-yielding, high manure treatment in 2001 (Figure 1), rendering the $\mathrm{N}$ unavailable for uptake. Compared to compost, manure had a C:N ratio $43 \%$ greater and 2.6 times as much total $\mathrm{C}$ 
(Table 1). In addition, earthworm activity, stimulated by the manure's organic matter, may have increased both macroporosity (not measured) and infiltration in manure-treated plots, leading to the leaching of $\mathrm{NO}_{3}-\mathrm{N}$ from the corn's root zone through preferential flow paths (Amlinger et al. 2003; Richard 2005). Infiltration did tend to increase with increasing manure rates in 2001 (data to be reported later in a manuscript in preparation).

\section{Slope Effects on Yield}

As noted previously, soil slope increased nearly 5.5-fold from span 1 to span 6 . Therefore, silage yield was characterized as a function of slope for each treatment without regard to the span on which the yield was measured. Silage yield decreased as slope increased for each treatment each year. These effects are illustrated in Figure 4 for the control and high manure treatments in 2000. The compost treatments are not shown because the slopes of their fitted relationships were similar to the control. Both relationships show a highly significant decrease in yield as slopes increased from 0.8 to $4.4 \%$. These decreases are a consequence, in part, of past years' irrigation-induced erosion (Carter 1990). In this study, silage yield decreased with increasing sediment losses in both 2000 and in 2001, with the decrease more pronounced the second year (Lehrsch and Kincaid, unpublished). Losses of surface soil likely removed nutrients, thus limiting yields.

Another cause, perhaps more likely, of yield decreases with increasing slope may have been water stress. Irrigation-induced erosion, particularly

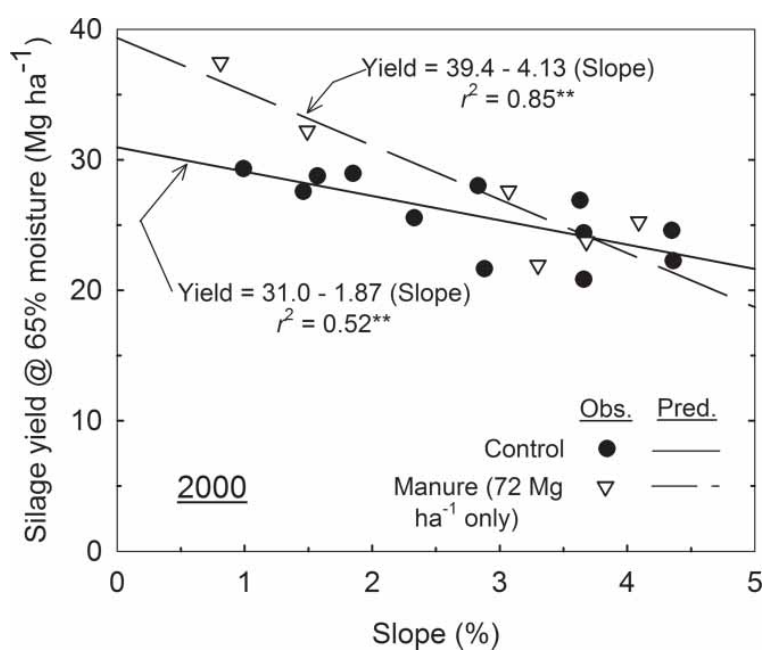

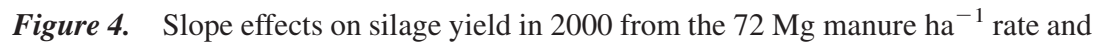
control treatments. 
from the steeper portions of the study site, removed portions of the Portneuf's relatively thin Ap horizon and, with subsequent tillage, increased the proportion of the Bk horizon in the corn's root zone. Rasmussen and Cary (1979) reported that when subsoil was mixed with topsoil, infiltration rates were about $38 \%$ less into mixed soil than surface soil. Lower infiltration rates lead to less recharge of the soil water reservoir, reduced water-use efficiency, more frequent water stress, lower yields, and increased runoff (Rasmussen and Cary 1979). Battiston, Miller, and Shelton (1987) attributed decreases in maize grain yield from eroded sites to 1) nutrient deficiencies, 2) moisture stress, and 3) reduced plant populations and seedling vigor due to poor seedbed conditions.

As slope increased, silage yield where $72 \mathrm{Mg}$ manure ha $^{-1}$ were applied decreased at a rate more than twice that where no manure was applied (Figure 4). Nonetheless, the slopes of the two fitted relationships were not different at the $P=0.05$ level, revealing that slope effects on yield were statistically similar from treatment to treatment. Where no amendments were applied, yield decreased on average nearly $1.9 \mathrm{Mg} \mathrm{ha}^{-1}$ with every unit increase in slope. Such findings highlight the requirement for controlling irrigation-induced erosion with polyacrylamide or other practices, particularly on steeper slopes, to sustain silage yields in the future (Larney et al. 2000; Lehrsch, Bjorneberg, and Sojka 2005). Producers must control or eliminate erosion that may increase field slope (Carter 1990; Lehrsch, Bjorneberg, and Sojka 2005). Management practices such as vegetated filter strips or buried minidrains decrease slopes by increasing deposition to eliminate convex slopes near field edges (Carter 1990). Findings illustrated in Figure 4 do not suggest that manure should not be applied to sloping fields. Indeed, data that account for slope effects shown in Figure 1 reveal that, compared to controls, yield increased, at times slightly and at times significantly, where moderate rates of both manure and compost were applied. Data in Figure 2 show that manure applied at rates up to about $29 \mathrm{Mg} \mathrm{ha}^{-1}$ increased yields more than controls. When producing corn silage, manure applications are recommended to replace nutrients taken off in silage and to improve soil structure (Rasmussen and Cary 1979; Tisdale and Nelson 1975).

\section{CONCLUSIONS}

In the first growing season after fall application of compost and manure, silage yields were similar for both amendments at both rates. In the second growing season, about 20 months after amendments were applied, compost at each rate increased yield compared to controls. Also in the second year, yield was less from the high manure rate than the medium. In 2001, yield increased initially, then decreased with increasing manure rates. Nitrogen uptake, averaged across years, was $230 \mathrm{~kg} \mathrm{ha}^{-1}$ from all amendment-treated plots, $15 \%$ more than controls. Yield for each treatment decreased linearly as slope 
increased. Yield tended to decrease at a greater rate with slope where excessive amounts of manure were applied, particularly in the first growing season after manure application.

In conclusion, silage yield increased in the second growing season after compost and manure were applied in the fall. Compost, applied at oven-dry rates up to $47 \mathrm{Mg} \mathrm{ha}^{-1}$, increased yields. Manure, on the other hand, increased yields only where applied at oven-dry rates up to $29 \mathrm{Mg} \mathrm{ha}^{-1}$.

\section{ACKNOWLEDGMENTS}

The authors thank P. M. Jolley, R. A. Dinges, R. D. McNurlin, and M. Roice for field operations, data collection, laboratory analyses, and preliminary data handling.

\section{REFERENCES}

Amlinger, F., Gotz, B., Dreher, P., Geszti, J., and Weissteiner, C. (2003) Nitrogen in biowaste and yard waste compost: Dynamics of mobilization and availability-a review. European Journal of Soil Biology, 39: 107-116.

Arriaga, F.J. and Lowery, B. (2003) Soil physical properties and crop productivity of an eroded soil amended with cattle manure. Soil Science, 168: 888-899.

Battiston, L.A., Miller, M.H., and Shelton, I.J. (1987) Soil erosion and corn yield in Ontario. I: Field evaluation. Canadian Journal of Soil Science, 67: 731-745.

Bresson, L.M., Koch, C., le Bissonnais, Y., Barriuso, E., and Lecomte, V. (2001) Soil surface structure stabilization by municipal waste compost application. Soil Science Society of America Journal, 65: 1804-1811.

Brown, B.D. (1988) Wheat Straw Management and Nitrogen Fertilizer Requirements; University of Idaho Agricutural Experiment Station: Moscow, Id.

Brown, B.D. and Westermann, D.T. (1988) Idaho Fertilizer Guide: Irrigated Field Corn for Silage or Grain; University of Idaho Agricultural Experiment Station: Moscow, Id.

Carter, D.L. (1990) Soil erosion on irrigated lands. In Irrigation of Agricultural Crops, Agron. Monograph 30, Stewart, B.A. and Nielson, D.R. (eds.); ASA, CSSA, and SSSA: Madison, Wisc., 1143-1171.

DeLuca, T.H. and DeLuca, D.K. (1997) Composting for feedlot manure management and soil quality. Journal of Production Agriculture, 10: 235-241.

Edmeades, D.C. (2003) The long-term effects of manures and fertilizers on soil productivity and quality: A review. Nutrient Cycling in Agroecosystems, 66: 165-180.

Edwards, J.H. and Someshwar, A.V. (2000) Chemical, physical, and biological characteristics of agricultural and forest by-products for land application. In Land Application of Agricultural, Industrial, and Municipal by-Products; Power, J.F. and Dick, W.A. (eds.); SSSA Book Series No. 6, Soil Science Society of America: Madison, Wisc., 1-62.

Eghball, B., Ginting, D., and Gilley, J.E. (2004) Residual effects of manure and compost applications on corn production and soil properties. Agronomy Journal, 96: 442-447. 
Hao, X. and Chang, C. (2003) Does long-term heavy cattle manure application increase salinity of a clay loam soil in semi-arid southern Alberta? Agriculture, Ecosystems and Environment, 94: 89-103.

Haynes, R.J. and Naidu, R. (1998) Influence of lime, fertilizer and manure applications on soil organic matter content and soil physical conditions: A review. Nutrient Cycling in Agroecosystems, 51: 123-137.

Jokela, W.E. (1992) Nitrogen fertilizer and dairy manure effects on corn yield and soil nitrate. Soil Science Society of America Journal, 56: 148-154.

Keener, H.M., Dick, W.A., and Hoitink, H.A.J. (2000) Composting and beneficial utilization of composted by-product materials. In Land Application of Agricultural, Industrial, and Municipal by-Products; Power, J.F. and Dick, W.A. (eds.); SSSA Book Series No. 6, Soil Science Society of America: Madison, Wisc., 315-341.

Kincaid, D.C. (2005) Application rates from center pivot irrigation with current sprinkler types. Applied Engineering in Agriculture, 21: 605-610.

Larney, F.J., Olson, B.M., Janzen, H.H., and Lindwall, C.W. (2000) Early impact of topsoil removal and soil amendments on crop productivity. Agronomy Journal, 92: 948-956.

Lehrsch, G.A. (1995) Soil-Temporal variation in aggregate stability. In 1996 McGraw-Hill Yearbook of Science and Technology; Parker, S.P. (ed.); McGrawHill: New York, 311-313.

Lehrsch, G.A., Bjorneberg, D.L., and Sojka, R.E. (2005) Erosion: Irrigation-induced. In Encyclopedia of Soils in the Environment; Hillel, D. (ed.); Elsevier: Oxford, U.K. vol. 1, 456-463.

Lehrsch, G.A. and Kincaid, D.C. (2001) Sprinkler droplet energy effects on infiltration and near-surface, unsaturated hydraulic conductivity. In Preferential Flow: Water Movement and Chemical Transport in the Environment; Bosch, D. and King, K.W. (eds.); ASAE: St. Joseph, Mich., 283-286.

Lehrsch, G.A. and Kincaid, D.C. (2005) Compost and manure effects on runoff, sediment loss, and aggregate stability under sprinkler irrigation. In Annual Meetings Abstracts [CD-ROM]; ASA, CSSA, SSSA: Madison, Wisc.

Lehrsch, G.A. and Kincaid, D.C. (2006) Sprinkler droplet energy effects on soil penetration resistance and aggregate stability and size distribution. Soil Science, 171: $435-447$.

Lehrsch, G.A., Sojka, R.E., Carter, D.L., and Jolley, P.M. (1991) Freezing effects on aggregate stability affected by texture, mineralogy, and organic matter. Soil Science Society of America Journal, 55: 1401-1406.

Lehrsch, G.A., Sojka, R.E., and Westermann, D.T. (2000) Nitrogen placement, row spacing, and furrow irrigation water positioning effects on corn yield. Agronomy Journal, 92: 1266-1275.

Liang, B.C., Remillard, M., and MacKenzie, A.F. (1991) Influence of fertilizer, irrigation, and nongrowing season precipitation on soil nitrate-nitrogen under corn. Journal of Environmental Quality, 20: 123-128.

Loveland, P. and Webb, J. (2003) Is there a critical level of organic matter in the agricultural soils of temperate regions? A review. Soil and Tillage Research, 70: 1-18.

Moffitt, D.C. (1992) Waste utilization. In USDA-NRCS National Engineering Handbook, Part 651: Agricultural Waste Management Field Handbook; Knider, J.N. (ed.); U.S. Government Printing Office: Washington, D.C., 11-1-11-36.

Rasmussen, W.W. and Cary, J.W. (1979) White Spots, Deep Tillage and Water Infiltration of the Portneuf and Related Silt Loam Soils; University of Idaho Agricultural Experiment Station: Moscow, Id. 
Richard, T.L. (2005) Compost. In Encyclopedia of Soils in the Environment; Hillel, D. (ed.); Elsevier: Oxford, U.K, vol. 1, 294-301.

Risse, L.M., Cabrera, M.L., Franzluebbers, A.J., Gaskin, J.W., Gilley, J.E., Killorn, R., Radcliffe, D.E., Tollner, E.W., and Zhang, H. (2001) Land application of manure for beneficial reuse. In White Papers on Animal Agriculture and the Environment; National Center for Manure and Animal Waste Management: Raleigh, N.C., 7.1-7.46.

Robbins, C.W., Freeborn, L.L., and Mackey, B.E. (1997) Improving exposed subsoils with fertilizers and crop rotations. Soil Science Society of America Journal, 61: $1221-1225$.

Robbins, C.W. and Gavlak, R.G. (1989) Salt- and Sodium-Affected Soils; Cooperative Extension Service Bulletin No. 703, University of Idaho Agricultural Experiment Station: Moscow, Id.

SAS Institute Inc. (1999) SAS/STAT User's Guide, Version 8; SAS Institute, Inc.: Cary, N.C., vol. 1-3.

Soil Science Society of America (1997) Glossary of Soil Science Terms; Soil Science Society of America: Madison, Wisc.

Sumner, M.E. (2000) Beneficial use of effluents, wastes, and biosolids. Communications in Soil Science and Plant Analysis, 31: 1701-1715.

Tarkalson, D.D., Jolley, V.D., Terry, R.E., and Robbins, C.W. (1998) Mycorrhizal colonization and nutrition of wheat and sweet corn grown in manure-treated and untreated topsoil and subsoil. Journal of Plant Nutrition, 21: 1985-1999.

Tiarks, A.E., Mazurak, A.P, and Chesnin, L. (1974) Physical and chemical properties of soil associated with heavy applications of manure from cattle feedlots. Soil Science Society of America Proceedings, 38: 826-830.

Tisdale, S.L. and Nelson, W.L. (1975) Soil Fertility and Fertilizers, 3rd edn.; Macmilian: New York.

Walker, J.M., Southworth, R.M., and Rubin, A.B. (1997) U.S. Environmental Protection Agency regulations and other stakeholder activities affecting the agricultural use of by-products and wastes. In Agricultural uses of by-Products and Wastes; Rechcigl, J.E. and MacKinnon, H.C. (eds.); ACS: Washington, D.C., 28-47.

Wolf, Nancy. (2003a) Determination of manure electrical conductivity (EC). In Recommended Methods of Manure Analysis; Peters, J. (ed.); Cooperative Extension Publication A3769, University of Wisconsin: Madison, Wisc., 50-51.

Wolf, Nancy. (2003b) Determination of manure pH. In Recommended Methods of Manure Analysis; Peters, J. (ed.); Cooperative Extension Publication. A3769, University of Wisconsin: Madison, Wisc., 48-49.

Wright, J.L., Westermann, D.T., and Lehrsch, G.A. (1998) Studying nitrate-N leaching with a bromide tracer in an irrigated silt loam soil. In Best Management Practices for Irrigated Agriculture and the Environment; Schaack, J., Freitag, A.W., and Anderson, S.S. (eds.); USCID: Denver, Col., 229-242. 